Review Article

\title{
An Overview of the Biological Effects of Some Mediterranean Essential Oils on Human Health
}

\author{
Hazem S. Elshafie and Ippolito Camele \\ School of Agricultural, Forestry, Food and Environmental Sciences, University of Basilicata, Viale dell'Ateneo Lucano 10, \\ 85100 Potenza, Italy
}

Correspondence should be addressed to Ippolito Camele; ippolito.camele@unibas.it

Received 13 June 2017; Revised 20 September 2017; Accepted 3 October 2017; Published 5 November 2017

Academic Editor: Yiannis Kourkoutas

Copyright (C) 2017 Hazem S. Elshafie and Ippolito Camele. This is an open access article distributed under the Creative Commons Attribution License, which permits unrestricted use, distribution, and reproduction in any medium, provided the original work is properly cited.

\begin{abstract}
Essential oils (EOs), extracted from aromatic plants, are interesting natural products and represent an important part of the traditional pharmacopeia. The use of some EOs as alternative antimicrobial and pharmaceutical agents has attracted considerable interest recently. Most of the EOs and their single constituents have been reported to inhibit several phytopathogens, human pathogens, and insects as well as their effective uses in food and pharmaceutical industries. The current review discussed the chemical composition and bioactivity of some important EOs extracted from some Mediterranean plants and their principal bioactive single constituents. Information has been furnished on the mechanisms, mode of actions, and factors affecting the bioactivity of some single constituents from different Mediterranean plant EOs. The current review gives an insight into some common plant EOs belonging to Lamiaceae, Apiaceae, Rutaceae, and Verbenaceae families commonly growing in Mediterranean region. Further information has been provided about the medical uses of some EOs for several human diseases covering the pharmacological effects (anti-inflammatory, antioxidant, and anticarcinogenic). The antimicrobial effects have been also considered in the current review. Although plant EOs are considered promising natural alternatives for many chemical drugs, they still need more specific research for wide application especially in food and pharmaceutical industries.
\end{abstract}

\section{Introduction}

Essential oils (EOs) are one of the most important natural products derived from plants for their various biological properties and medicinal uses $[1,2]$. EOs have been utilized in different domestic aspects such as in perfumery, cosmetics, feed, food, and beverages. Several researchers demonstrated the possibility of utilizing EOs in cooking, where they give a pleasant taste to food and are utilized mostly in processed food. Recently, there has been great interest in the use of EOs for their curative effects in aromatherapy [3]. Plant EOs were largely utilized in pharmaceutical and other related medical uses as one of the most important and effective ingredients.

The current review intends to discuss some aspects of plant EOs and their main single constituents ranging from an overview of historical perspective, analytical techniques for chemical analysis (classical and modern methods), bioactivity of single substances (mode of action, factors affecting their bioactivity, and common families of aromatic Mediterranean plants), medical uses for human health and biological characterization including pharmacological aspects (antiinflammatory, antioxidant, and anticarcinogenic effects), and antimicrobial effects (antibacterial and antifungal activities).

This review gives also an insight into the chemical composition of some important EOs and their principal bioactive single constituents. Detailed information focuses on the mechanism of bioactivity action of the main bioactive single constituents of some important plant EOs such as sage, oregano, thyme, marjoram, and vervain related to different families such as Lamiaceae, Apiaceae, Rutaceae, and Verbenaceae.

\section{History of Plant Essential Oils}

EOs have been used by many cultures around the world for centuries for different purposes according to each culture. It 
is unknown exactly whether the EOs were used as healing agents or for domestic use in the beginning. However, recently great consideration has been given to the effective use of EOs in clinical procedures [4-6].

Ancient Egyptians have used aromatic oils as early as 4500 BC in cosmetics and ointments [7]. They used to make a mixture of different sources of herbal preparations such as aniseed, cedar, onion, myrrh, and grapes in perfume or medicine [7]. On the other hand, the use of aromatic oils was first recorded in traditional Chinese and Indian medicine between 3000 and 2000 BC [7]. In particular, the recorded history about China and India listed more than 700 substances including cinnamon, ginger, myrrh, and sandalwood as being effective for healing. In addition, Greek history documented the use of different EOs for the first time between 500 and $400 \mathrm{BC}$, including thyme, saffron, marjoram, cumin, and peppermint [8].

In the 18th and 19th centuries, chemists documented the active components of medicinal plants and identified many substances such as caffeine, quinine, morphine, and atropine, which were considered to play an important role in their biological effects [9].

Some EOs such as lavender, peppermint, and myrrh are still being used pharmaceutically and could be used effectively in the upcoming future as suitable alternatives for many synthetically produced medications [3].

\section{Chemical Composition of Plant Essential Oils}

As widely known, the chemical composition of plant EOs is principally represented by mono- and sesquiterpene hydrocarbons and their oxygenated derivatives, along with aliphatic aldehydes, alcohols, and esters [7]. It is also of great interest to highlight that the chemical profile of any EO is closely related to the extraction procedure carried out and therefore the selection of suitable extraction method is very important.

According to the characteristics of each plant material, some specific extraction techniques can be applied such as steam distillation, solvent extraction, soxhlet extraction, microwave-assisted hydrodistillation, dynamic headspace, static headspace, solvent flavor evaporation, solid-phase microextraction, and direct thermal desorption [7].

\subsection{Analytical Techniques}

3.1.1. Classical Analytical Techniques. Generally, the traditional classical techniques for analysis EOs were mainly focused on the quality aspects of oil, concerning mainly two properties, namely, identity and purity [10]. The following techniques are commonly applied to assess the physical properties of any EO: specific gravity, optical rotation, and determination of the refractive index [11]. Another test is for assessment of EO purity such as the presence of polar substances, like alcohols, glycols, and their esters and glycerin acetates. In addition to the solubility test of an EO in ethanol this reveals much on its quality [11]. The measurement of melting and congealing points as well as the boiling range of an EO is also of great importance for identifying its purity [11]. Another test usually performed in EO analysis is the evaporation residue, in which the percentage of the oil that is not released at $100^{\circ} \mathrm{C}$ is determined.

On the other hand, classical methodologies have been widely applied to assess the chemical properties of EOs [10, 11], such as the determination of halogenated hydrocarbons and heavy metals. The determination of esters derived from phthalic acid is also of great interest for the toxicity evaluation of an EO [10]. In most of the cases, the classical methods are generally focused on chemical groups and also the quantification method by titration such as the acidimetric determination of saponified terpene esters. A further test is the determination of terpene alcohols by acetylating with acetic anhydride [12]. Aldehydes and ketones could be estimated through different tests like bisulfite method which is recommended for aldehyde-rich oils such as lemongrass, bitter almond, and cassia, while the neutral sulfite test is more suitable for ketone-rich oils such as spearmint, caraway, and dill oils [12]. The chromatographic methods are considered as one of the most common and easily analytical techniques in EOs analysis. The principle of chromatography is based on the distribution of the constituents to be separated between two immiscible phases [13]. Thin Layer Chromatography (TLC) is a fast and inexpensive method for identifying substances and testing their purity [14].

The use of the above-mentioned traditional analytical techniques for the systematic study of EOs is generally applied for the assessment of pure compounds as well as some major compounds. Classical methods need to be combined with some modern analytical techniques, such as Gas Chromatography-Mass Spectrometry (GC-MS).

3.1.2. Modern Analytical Techniques. Most of the modern analytical techniques of EOs depend on chromatographic procedures. The main objective in any chromatographic separation is always the complete resolution of the compounds in the minimum time; for that, the most appropriate analytical chromatographic column with a specific dimension and stationary phase has to be used under adequate chromatographic conditions.

In particular, the GC analysis can be summarized as the evaporation of the compound and the elution by the mobile gas phase, the carrier gas, through the column. The different substances are separated on the basis of their relative vapor pressures and affinities for the stationary bed. On the other hand, the liquid chromatographic analysis depends on the elution of the compound by a liquid mobile phase consisting of a solvent or a mixture of solvents and the different substances are separated according to their affinities for the stationary bed.

Mass Spectrometry (MS) can be defined as the study of systems through the formation of gaseous ions, with or without fragmentation, which are then characterized by their mass-to-charge ratios $(\mathrm{m} / z)$ and relative abundances [15]. GC-MS is an analytical method that combines the features of Gas Chromatography and Mass Spectrometry to identify different substances within a test sample [16]. 
Applications of GC-MS include drug detection, fire investigation, environmental analysis, explosives investigation, and identification of unknown samples. GC-MS is composed of two major building blocks: the gas chromatograph and the mass spectrometer. The gas chromatograph utilizes a capillary column which depends on the column's dimensions and the phase properties. The difference of the chemical properties between different molecules in a mixture and their relative affinity for the stationary phase of the column will promote their separation. Different molecules are retained by the column and then are eluted from the column at different retention times [16]. A list of some single constituents that exist in common aromatic Mediterranean plants have been reported in Table 1.

\section{Bioactivity of Plant EOs and Their Single Components}

The bioactivity of EOs is the sum of its constituents which act either in a synergistic or in an antagonistic way [7, 17]. The term "bioactivity" could be used for all EOs as well as their main active constituents either stable or volatile such as monoterpenes, sesquiterpenoids, benzenoids, and phenylpropanoids which demonstrate a sort of biological activity on humans, animals, and plants.

The following part of the current review covers the following points: (i) mode of action of single components; (ii) factors affecting the single components bioactivity.

4.1. Mode of Action. Most antimicrobial activities of several plant EOs depend mainly on their bioactive single components which are able to inhibit the growth of microorganisms and/or completely suppress the pathogens [17, 18]. In fact, several studies have explained that the synergetic effect between two or more chemical constituents could have a distinctive role in the biological activity of EOs [19].

The synergism between the aromatic plant components often plays an essential role in the effectiveness and reduction of the developing resistance of any pathogenic microorganism. Therefore, some constituents such as carvacrol, $\gamma$ terpinene, and p-cymene are more effective when they are combining together [20]. This synergistic action is due to $\mathrm{p}$ cymene which acts as a mediator for carvacrol transportation across cell wall components and the cytoplasmic membrane of pathogenic fungi. Furthermore, the enzymatic reactions within the EOs and the lipophilic properties of the individual bioactive constituents might play a role in degrading the microbe plasma membrane and hence lead to the lyses of the hypha wall as discussed by Soylu et al. (2010) [21].

4.2. Factors Affecting the Bioactivity of EOs Composition. The composition of each EO can vary depending on certain conditions such as plant variety, plant part, growth area, climatic changes, harvesting time, storage conditions, and the chemotype of each component [8]. Therefore, the composition of EOs cannot be expected to be similar every year even if they are extracted from the same area. For example, the minimum inhibitory concentrations (MICs) of four different chemotypes of thyme oil (linalool, thuyanol, carvacrol, and thymol type) against Staphylococcus aureus Rosenbach ranged from 250 to $4000 \mu \mathrm{g} / \mathrm{mL}$ depending on the presence of thymol [22].

For improving the antimicrobial outfindings of many plant EOs, several factors either biological and experimental should be taken into consideration such as (i) appropriate and exact standardized microbiological test; (ii) available standard strains from different collections; (iii) assays including a variety of microorganisms either gram-positive and gramnegative bacteria, phytopathogens and human pathogens and yeasts; (iv) exact botanical identification of the plant EOs origin; (v) biochemical characterization of the extracted EOs as well as their production, storage conditions, and age. In addition, the distinctive water solubility and volatility of many EOs enable them to reveal a broadband spectrum of activity in various in vitro tests such as agar well diffusion, serial dilutions, and volatile tests [23].

Several plant EOs demonstrated different antimicrobial activities according to the tests carried out, examiners themselves, or any other factors. For example, lemon EO showed to some extent a clear inhibition effect against Escherichia coli Migula by using agar diffusion test as reported by Fisher and Phillips (2006) [24]. However, other researchers did not notice any inhibition activity from lemon oil against the same target organism using another nutrient media iso-sensitest agar [25].

Möse and Lukas (1957) [26] have observed a clear inhibition activity from lemon oil against Klebsiella pneumonia Schroeter in agar diffusion test, whereas Deans and Ritchie (1987) [25] reported that there is no antibacterial effect from lemon oil against this bacterium. The obtained results of MIC test showed diverse actions regarding the antibacterial activity of rosemary oil against $S$. aureus ranging from 20 to $400 \mu \mathrm{g} / \mathrm{mL}$ as reported by Panizzi et al. (1993) [27] due to differences in incubation period even at the same temperature.

On the other hand, Pellecuer et al. (1976) [28] reported the highest MIC value $(1250 \mu \mathrm{g} / \mathrm{mL})$ regarding rosemary oil obtained in the dilution test against Bacillus subtilis Ehrenberg, whereas Farag et al. (1989) [29] observed a moderate MIC value (750-800 $\mu \mathrm{g} / \mathrm{mL})$. However, Panizzi et al. (1993) [27] reported the lowest MIC value of the same oil $(10 \mu \mathrm{g} / \mathrm{mL})$ and these changes in estimated values could be due to the fluctuation of some experimental factors like temperature and incubation period.

\section{Common Mediterranean Aromatic Plants}

Many common Mediterranean aromatic plants are belonging to Lamiaceae, Apiaceae, Rutaceae, and Verbenaceae families. The selected discussed aromatic plants in the current review are considered as the most important Mediterranean officinal plants.

\subsection{Family Lamiaceae}

5.1.1. Lavender. The EO extracted from lavender (Lavandula officinalis Chaix.), Lamiaceae family, showed strong antibacterial and antifungal properties [30]. L. officinalis EO treats sinus and vaginal infections due to Candida albicans 
TABLE 1: List of some single constituents existing in common aromatic Mediterranean plants.

\begin{tabular}{|c|c|c|}
\hline Number & $\begin{array}{l}\text { Main single } \\
\text { constituent }\end{array}$ & Common aromatic plants \\
\hline (1) & $\alpha$-Thujene & Dill, balm, caraway, lavender, marjoram, oregano, sage \\
\hline (2) & Camphene & Mint, hyssop, lavender, marjoram, oregano, sage, thyme \\
\hline (3) & Sabinene & Dill, parsley, basil, caraway, marjoram, sage \\
\hline$(4)$ & Myrcene & Dill, parsley, mint, balm, basil, caraway, fennel, hyssop, lavender, marjoram, oregano, sage \\
\hline (5) & $\beta$-Pinene & Dill, parsley, balm, basil, caraway, fennel, marjoram, oregano, sage \\
\hline (6) & cis-3-Hexenyl acetate & Parsley, coriande, mint \\
\hline (7) & $\alpha$-Terpinene & Mint, balm, hyssop, marjoram, oregano, thyme \\
\hline$(8)$ & p-Cymene & Dill, parsley, mint, balm, caraway, fennel, lavender, marjoram, oregano, sage, thyme \\
\hline (9) & $\beta$-Phellandrene d & $\begin{array}{l}\text { Dill, parsley, balm, basil, caraway, fennel, hyssop, lavender, marjoram, oregano, sage, } \\
\text { thyme, vervain }\end{array}$ \\
\hline (10) & trans- $\beta$-Ocimene & Dill, parsley, mint, basil, caraway, hyssop, lavender, marjoram, vervain \\
\hline (11) & $\gamma$-Terpinene & Parsley, mint, balm, fennel, hyssop, lavender, marjoram, oregano, sage, thyme, vervain \\
\hline (12) & Terpinolene & Balm, basil, hyssop, marjoram, oregano, thyme \\
\hline (13) & Linalool & Mint, balm, basil, caraway, hyssop, lavender, marjoram, oregano, sage, thyme, vervain \\
\hline (14) & Nonanal & Coriander, mint \\
\hline (15) & Limonene & Mint, balm, basil, caraway, hyssop, lavender, marjoram, oregano, sage, thyme, vervain \\
\hline (16) & $\begin{array}{l}\text { trans-p-Mentha-2.8- } \\
\text { dien-1-ol }\end{array}$ & Mint \\
\hline (17) & $\alpha$-Terpineol & Parsley \\
\hline (18) & Carvomenthyl acetate & Mint \\
\hline (19) & Bornyl acetate & Mint, caraway, lavender, marjoram, sage \\
\hline$(20)$ & E-2-Undecenal & Coriander \\
\hline (21) & 1-Undecanol & Coriander \\
\hline$(22)$ & cis-Carveol & Mint, basil \\
\hline$(23)$ & $\alpha$-Pinene & Dill, mint, balm, basil, marjoram, oregano, sage, thyme, vervain \\
\hline$(24)$ & trans-Carveol & Mint, hyssop, sage \\
\hline$(25)$ & Carvone & Dill, coriander, \\
\hline$(26)$ & $\alpha$-Phellandrene & Dill, parsley, fennel, lavender, marjoram, oregano \\
\hline$(27)$ & $\beta$-Caryophyllene & Mint, balm, basil, caraway, hyssop, lavender, marjoram, oregano, sage, thyme, vervain \\
\hline$(28)$ & Dodecanal & Coriander \\
\hline$(29)$ & $\begin{array}{l}\text { trans- } \beta- \\
\text { Caryophyllene }\end{array}$ & $\begin{array}{l}\text { Parsley, mint, balm, basil, caraway, hyssop, lavender, marjoram, oregano, sage, thyme, } \\
\text { vervain }\end{array}$ \\
\hline$(30)$ & $\alpha$-Humulene & Mint \\
\hline (31) & cis-Pinane & Basil, caraway, lavender, oregano \\
\hline (32) & D3-Carene & Fennel, lavender, marjoram, oregano \\
\hline (33) & a-Terpinene & Balm, hyssop, marjoram, oregano \\
\hline$(34)$ & $o$-Cymene & Anise, balm, basil, caraway, hyssop, lavender, marjoram, oregano, sage, thyme, vervain \\
\hline$(35)$ & p-Cymene & Caraway, fennel, lavender, marjoram, oregano, sage, thyme \\
\hline$(36)$ & 1,8-Cineole & Balm, basil, hyssop, marjoram, oregano, sage, vervain \\
\hline$(37)$ & cis-Linalool oxide & Anise, basil, fennel \\
\hline$(38)$ & (-)-Citronellal & Balm, sage, thyme \\
\hline$(39)$ & iso-Borneol & Balm, marjoram, thyme \\
\hline$(40)$ & Camphor & Balm, basil, lavender, marjoram, sage \\
\hline (41) & iso-Pinocamphone & Basil, hyssop, lavender, marjoram, oregano, sage \\
\hline$(42)$ & trans-Pinocamphone & Balm, caraway, hyssop, sage \\
\hline$(43)$ & Terpinen-4-ol & Balm, basil, hyssop, lavender, marjoram, oregano, sage, vervain \\
\hline$(44)$ & Myrtenol & Basil, hyssop, lavender, marjoram, sage, thyme \\
\hline$(45)$ & (E)-Citral & Vervain, oregano \\
\hline
\end{tabular}


TABle 1: Continued.

\begin{tabular}{lcl}
\hline Number & $\begin{array}{c}\text { Main single } \\
\text { constituent }\end{array}$ & Common aromatic plants \\
\hline$(46)$ & Isobornyl acetate & Caraway, lavender, marjoram, sage \\
$(47)$ & Bornyl acetate & Caraway, lavender, marjoram, sage \\
$(48)$ & Thymol & Balm, marjoram, oregano, thyme \\
$(49)$ & a-Copaene & Basil, hyssop, marjoram, oregano, vervain \\
$(50)$ & b-Elemene & Balm, basil, caraway, vervain \\
$(51)$ & b-Caryophyllene & Balm, basil, caraway, hyssop, lavender, marjoram, oregano, sage, thyme, vervain \\
$(52)$ & b-Cedrene & Balm, basil, hyssop, lavender, marjoram, oregano, sage, vervain \\
$(53)$ & a-Humulene & Balm, basil, hyssop, lavender, marjoram, oregano, sage, vervain \\
$(54)$ & Caryophyllene oxide & Balm, lavender, oregano, sage \\
\hline
\end{tabular}

Berkhout and digestive disturbances including colic and helps to boost immunity [31].

Furthermore, lavender EO was well documented for the treatment of abrasions, burns, stress, headaches, skin problems, muscular pain, and boosting the immune system $[32,33]$. The lavender EO is chemically composed of camphor, terpinen-4-ol, linalool, linalyl acetate, beta-ocimene, and 1,8-cineole (Table 2) [34]. Among the above-mentioned substances, linalool and linalyl acetate showed a sedative effect and marked narcotic actions, respectively. In addition, linalool and linalyl acetate have great absorbing properties for skin during massages.

5.1.2. Oregano. Oregano (Origanum vulgare L.), Lamiaceae family, is a perennial herb; it is considered as one of the most common culinary herbs where its leaves can enhance the flavor of food [19]. This species is used in traditional and modern medicine and in the pharmaceutical industry.

Four main groups of oregano commonly used as culinary herbs can be distinguished, that is, Greek oregano (Origanum vulgare L. ssp. hirtum (Link) Ietsw.), Spanish oregano (Coridothymus capitatus (L.) Hoffmanns. \& Link), Turkish oregano (O. onites L.), and Mexican oregano (Lippia graveolens Kunth) [35]. O. vulgare L. ssp. hirtum is a typical eastern Mediterranean taxon, reported only for some areas in Southern Italy [36]. The main single constituents of O. vulgare EO have been listed in Table 2 .

5.1.3. Thymus. The most common variety is Thymus vulgaris L. It belongs to the genus Thymus of the Lamiaceae family. The EO extracted from $T$. vulgaris EO showed antimicrobial activity against several phytopathogens such as $B$. cinerea, Penicillium italicum Wehmer, P. citrophthora Leonian, and Rhizopus stolonifer (Ehrenb.) Vuill. [37].

Thymus species are used as food plants by the larvae of some Lepidoptera (butterfly and moth) insect species, including Chionodes distinctella and the Coleophora case-bearers $C$. lixella, C. niveicostella, C. serpylletorum, and C. struella [38]. The main single constituents of T. vulgaris EO have been listed in Table 2.

5.1.4. Peppermint. The most important species are peppermint (Mentha piperita L.) and spearmint (M. spicata L.).
M. piperita was classified in the Lamiaceae family; their oil constituents include carvacrol, menthol, carvone, methyl acetate, limonene, and menthone [6].

Peppermint EO has been intensively studied for its antiinflammatory, anti-infectious, antimicrobial, and fungicidal effect as well as antiseptic and digestive properties. It is observed that the single constituents of peppermint EO can relieve many bacterial, fungal, and viral infections when inhaled or applied in the form of vapor balm. On the other hand, Ali et al. (2015) [3] reported that menthol, the primary constituent of peppermint EO, is responsible for pharmacological action.

5.1.5. Sage. Sage is considered to be the main genus among the Lamiaceae family, which consists of about 900 species widely distributed in the temperate, subtropical, and tropical regions all over the world but especially in the Mediterranean region, central Asia, central and South America, and southern Africa [19].

Globally, the best known species of the family used in both traditional and modern medicine are Salvia officinalis, S. fruticosa, and S. divinorum. Another important plant is oregano, considered to be the most valued species worldwide. About 60 plant species were listed within this common name. The main single constituents of sage EO have been listed in Table 2.

5.1.6. Marjoram. Majorana hortensis (Lamiaceae), commonly known as marjoram, is a perennial herb or undershrub with sweet pine and citrus flavors. It has a long history of medicinal and culinary use. In some Middle Eastern countries, marjoram is synonymous with oregano; therefore, some names have been used to distinguish it from other plants of the genus Origanum such as sweet marjoram and knotted marjoram [39]. The main single constituents of marjoram EO have been listed in Table 2 .

\subsection{Family Apiaceae}

5.2.1. Anise. Pimpinella anisum (Apiaceae) is called aniseed. It is native to the eastern Mediterranean region and Southwest Asia [40]. Anise is an herbaceous annual plant; its leaves at the base of the plant are simple, long, and shallowly lobed, while 


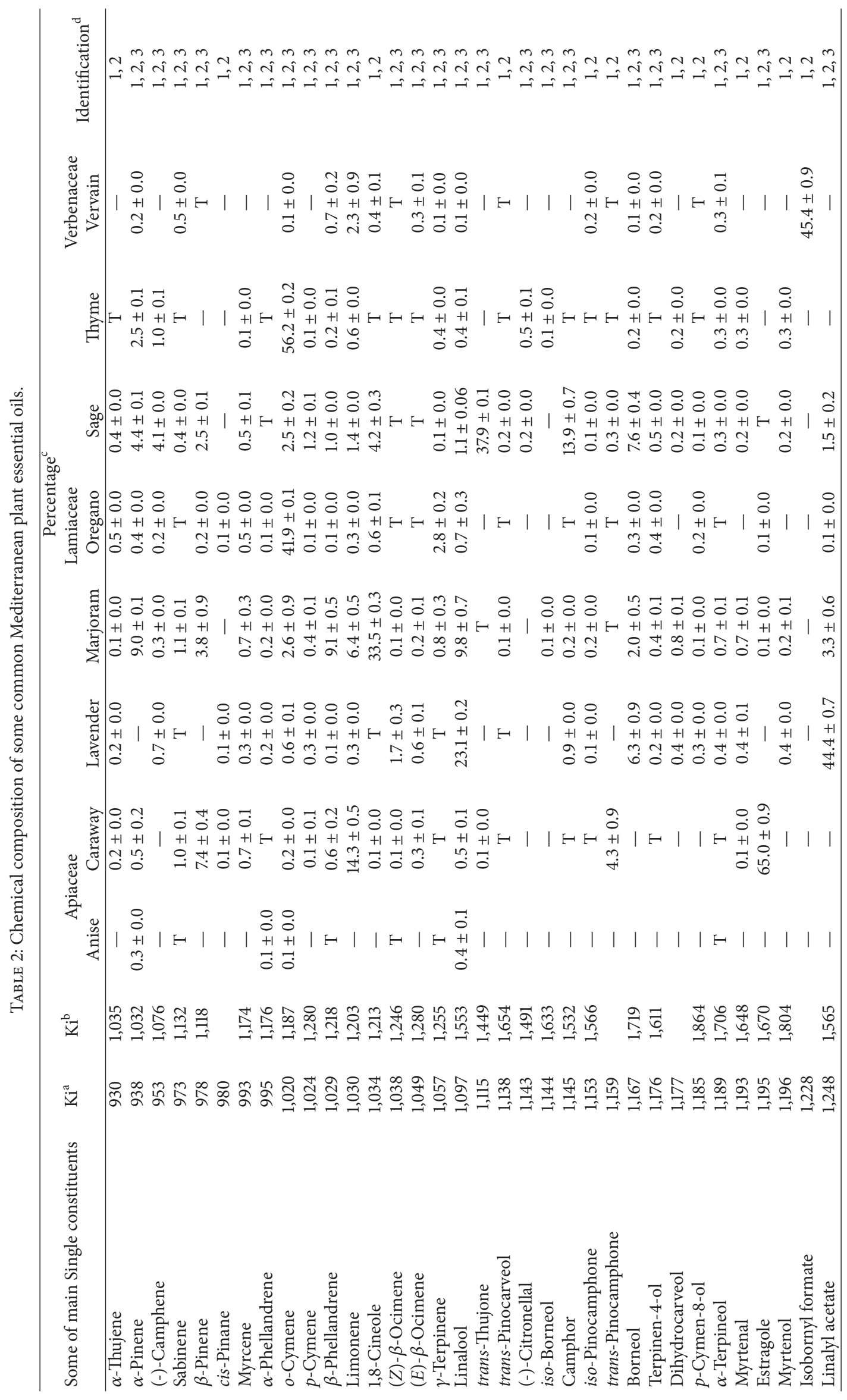




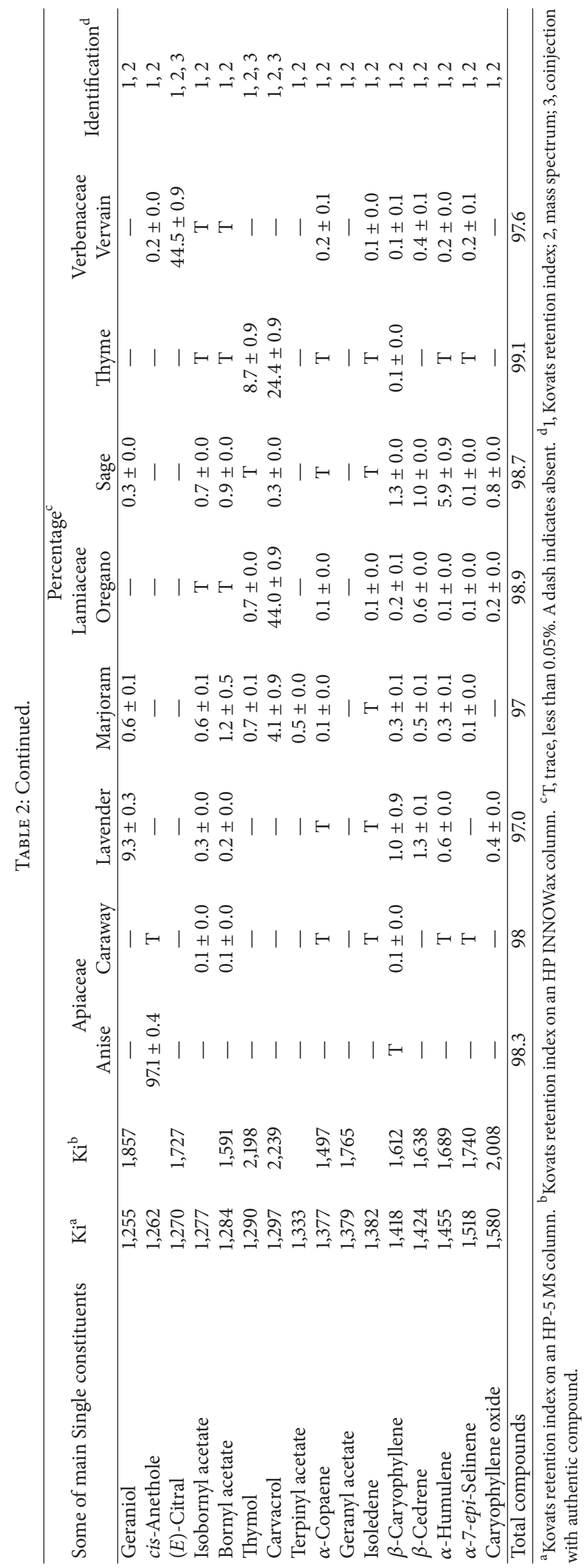


its higher leaves are feathery pinnate, divided into numerous small leaflets.

Anise is a food plant for the larvae of some Lepidoptera species such as butterflies and moths. Anise was first cultivated in Egypt and the Middle East and was brought to Europe for its medicinal value [41]. Anise EO can be obtained from the fruits by the steam distillation technique. The main component of anise EO is anethole (80-90\%), with minor components including 4-anisaldehyde, estragole, and pseudoisoeugenyl-2-methylbutyrates [42].

5.2.2. Caraway. Carum carvi (Apiaceae) is called also meridian fennel. It is native to some parts of Mediterranean region like western Asia, Europe, and North Africa [43].

The plant characterized by finely divided, feathery leaves with thread-like divisions. The fruits of caraway are usually used as a whole and have a pungent, anise-like flavor and aroma that comes from its EO such as carvone, limonene, and anethole. The main single constituents of caraway EO have been listed in Table 2. Caraway fruit oil is used as a fragrance component in some cosmetic industries such as lotions and perfumes; in addition it has many uses in folk medicine [44].

\subsection{Family Rutaceae}

5.3.1. Lemon. Lemon, Citrus limon L. (Osbeck) is a species of small evergreen tree in the flowering Rutaceae family native to Asia. The EO extracted from C. limon is composed mainly of terpenes, D-limonene, and limonene. In addition, some other minor constituents are present in trace amounts such as phellandrene, pinene, and sesquiterpene [34].

Lemon EO is able to accelerate the production of white blood cells, strengthen the immune system, and help in the digestion processes [32]. The main constituents of lemon EO have demonstrated antiseptic, astringent, and detoxifying properties for blemishes associated with oily skin [45].

\subsection{Family Verbenaceae}

5.4.1. Vervain. Verbena officinalis L. classified in Verbenaceae family is commonly known as vervain. It is natively grown in Europe. Verbena has been traditionally used in herbalism and folk medicine, as herbal tea. Among other effects, it may act as a galactagogue and possibly sex steroid analogue. Verbena has been listed as one of the 38 plants used to prepare Bach flower remedies [46].

Several researches reported the antimicrobial activity of vervain $\mathrm{EO}$ and investigated that this activity could be related to the high amounts of monoterpenes and phenolic compounds. In fact, the major constituents of this EO were $o$ cymene, isobornyl formate, citral, carvacrol, and thymol [19]; further details of the main components of vervain $\mathrm{EO}$ have been reported in Table 2 .

\section{Medical Uses of Essential Oils in Human Diseases}

Many of the plant EOs are being widely utilized in the pharmaceutical industry, aromatherapy, and other related medical uses. Many plant EOs have been used as medicine for centuries and have demonstrated several health benefits, including effects on infectious, chronic, and acute diseases [47].

The medical preparations made with plant EOs as well as their single constituents applied in the therapy of human infectious diseases are well documented. However, the selection of the suitable safe oil and the determination of the best efficient dose should be taken into consideration to avoid any side effects when they are applied for children presupposes. In particular, many EOs have been used for healing purposes and have been highly recommended especially in the treatment of some catarrhal diseases [47]. Eugenol 3, the main constituent of clove (Syzygium aromaticum L. Merrill \& Perry) EO, can treat the systemic infections of children with fever; however, a prior study reported that it was not sufficient to prevent death among all treated patients [7]. Several investigations showed that Ocimum gratissimum L. EO was more effective than benzyl peroxide-based products for reducing the number of lesions (papules and pustules) [48].

A number of medical trials have investigated the effective use of some EOs in treating methicillin-resistant $S$. aureus (MRSA) in vitro, for example, Lippia origanoides Kunth, Backhousia citriodora F. Muell, $M$. piperita, $M$. arvensis, $M$. spicata, and Melaleuca alternifolia (Maiden \& Betche) Cheel [17]. Further studies reported the effective use of EO extracted from Citrus aurantium var. amara L. in inhibiting Tinea corporis disease even at low concentrations.

The detailed pharmacological effects of many plant EOs such as anti-inflammatory, antioxidant, and anticarcinogenic were also discussed in the following section.

6.1. Pharmacological Activity. Recently, great interest was given to the curative effect of many plant EOs especially for wound treatment since the EOs have demonstrated interesting medication against some wound types, which cannot occur with pharmaceuticals [49].

For centuries, plant EOs have been used for curing many diseases such as melaleuca EO which is considered an effective factor for speeding up the healing process of wounds. Lavender EO was commonly used to heal wounds, cuts, burns, and sunburns by improving the formation of scar tissues [8]. Tea tree oil has been shown to be effective in vitro on several strains of methicillin-resistant $S$. aureus (MRSA) isolated from wounds [50]. The EOs extracted from frankincense and geranium can be used as antiseptic agents by burning them. They can also be applied internally to protect the wounds from developing infections [51].

6.1.1. Anti-Inflammatory. Inflammatory disorders are associated with pain, redness, and swelling, leading to loss of vital functions. EOs have been used for several decades to relieve pain and inflammation. Usually, EOs have more effective and pain-relieving properties than many pharmaceutical analgesics. The use of EOs has many benefits in the treatment of inflammation because it has fewer side effects than many synthetic and traditional drugs. 
A review of the medicinal properties of chamomile documented that plants contain more flavonoids with anti-inflammatory properties than others do. These inflammationreducing compounds can penetrate the skin easily and reduce inflammation. Tea tree oil has been shown to increase monocytic differentiation in vitro and reduce inflammation, therefore assisting the healing of chronic wounds. Other promising applications have been proposed for Helichrysum italicum (Roth) G. Don as antispastic [52], Pelargonium roseum L'hér. as anti-inflammatory [53], and O. majorana L. as antimutagenic agent [54].

The possible mechanism of the anti-inflammatory property of EOs was suggested to compete with arachidonic acid for its incorporation into the membrane. Hence, arachidonic acid generates slightly modified prostaglandins and eicosanoids, which induces a lesser extent of inflammation via reduced induction of COX-2 [55]. Further studies reported that the main component of tea tree oil, terpinen4-ol, has been shown to suppress inflammatory mediator production by activating monocytes in vitro [50].

6.1.2. Antioxidant. Antioxidant activity can be defined as the molecules able to react with radicals or having a reducing power to counteract the oxidative stress caused by radicals. Antioxidant properties play an essential role in some of EOs' biological activities, which is justified by the involvement of oxidative stress in pathology. In addition, the botanical source of aromatic plants and the environmental factors such as climate may affect the actual composition of extracted EOs and thus reflect different antioxidant activities. Oregano EO is able to protect extra virgin olive oil from oxidation during storage and is able to extend the shelf life of sea bream and to reduce the formation of volatile amines and of TBAR compounds [56]. Oregano and sage EOs are able to protect the minced meat samples from autoxidation [57].

The antioxidant effect of many EOs is due to the inherent ability of some of their components, particularly phenols, to stop or delay the aerobic oxidation of organic matter [58]. On the other hand, there are phenol-free EOs that express antioxidant behaviour and this is due to the radical chemistry of some terpenoids and other volatile constituents (e.g., sulfurcontaining components) [48]. In general, phenolic compounds, both natural (e.g., $\alpha$-tocopherol) or synthetic (e.g., BHA), act as antioxidants due to their high reactivity with peroxyl radicals, which are disposed of by formal hydrogen atom transfer [59]. The antioxidant chemistry of sulfurcontaining EOs from Allium and related genera is due to a direct chain-breaking activity that is expressed only upon conversion of the inactive components into thiosulfinates that ultimately yields the "active" sulfonic acid [57].

6.1.3. Anticarcinogenic. Anticarcinogenic activity is the ability of a specific substance to counteract or completely inhibit the development of carcinogen. The traditional anticancer therapy, such as multichemotherapeutic drugs, is often compromised of the development of drug resistance and the serious irreversible side effects [60]. As pointed out recently, natural products from medicinal plants represent a fertile ground for the development of novel anticancer agents. However, the utilization of plant EOs as anticancer agents is under daily diagnosis for designing the best natural alternative, which could have selectivity towards the target cells of various tumours.

In the current review, some revealing examples of plant EOs and their constituents that have been used effectively as antitumour agents have been discussed. The detailed discussion will also be reported regarding the possible mechanisms and the multiple pathways involving apoptosis, DNA repair modulation, cell cycle arrest, and antiproliferative activity through the increase of reactive oxygen and nitrogen levels (ROS/RNS) in cancer cells [61].

Some EOs showed a potential anticancer activity against liver, lung, colon, and prostate cancer such as Artemisia lavandulaefolia DC and its main single constituent 1,8-cineole against a subline of the ubiquitous KERATIN-forming tumour cell line HeLa which derived from an epidermal carcinoma of the mouth [62]. Jayaprakasha et al. (2013) [63] found that $C$. limettioides Tan EO inhibited colon cancer (SW480) by inducing the cells-apoptosis. Zu et al. (2010) [64] noted that the T. vulgaris EO exhibited the strongest cytotoxicity towards three human cancers: PC-3 from human prostate, A549 from human lung, and MCF-7 from breast adenocarcinoma.

Further studies demonstrated that some single constituents like carvacrol [65], thymol [66], limonene, and citral [67] have shown a promising cytotoxic effect against different human cancer cell lines mainly due to the induction the mitochondrial dysfunction [65-67]. Elshafie et al. [68] have pointed out the effectiveness of $O$. vulgare $\mathrm{EO}$ and its main single constituents (carvacrol, thymol, citral, and limonene) on tumour liver cell line (HepG2) following the MTT viability assay. The results showed that the above treatments illustrated a great effect as anticancer therapeutic agents especially thymol and carvacrol (Figure 1).

The general mechanism of cytotoxic effect of plant EOs is mostly due to the presence of phenols, aldehydes, and alcohols. In particular, the toxicity towards mammalians decreases significantly with the increase of average lipophilicity of EO components [51], while the toxicity against bacteria and fungi simultaneously increases significantly with increasing lipophilicity [51]. This mode of action refers to the extraordinary role of EOs among natural compounds, especially of their highly lipophilic constituents. The cellular mechanisms of carcinogenic prevention by EO treatments were also considered to be due to the induction of cellapoptosis [61]. There is also a suggestion that the pathway of cancer cells is sensitive to the inhibitory actions of plant isoprenoids by reducing tumour cell-size in patients [69].

\section{Antimicrobial Activity}

7.1. Antibacterial. Elshafie et al. (2016) [70] evaluated the in vitro antibacterial activity of three EOs extracted from Schinus terebinthifolius Raddi (leaves and fruits) against two strains of G+ve bacteria (Bacillus megaterium de Bary and Clavibacter michiganensis Smith) and 4 strains of G-ve bacteria (E. coli, Xanthomonas campestris Pammel, Pseudomonas 


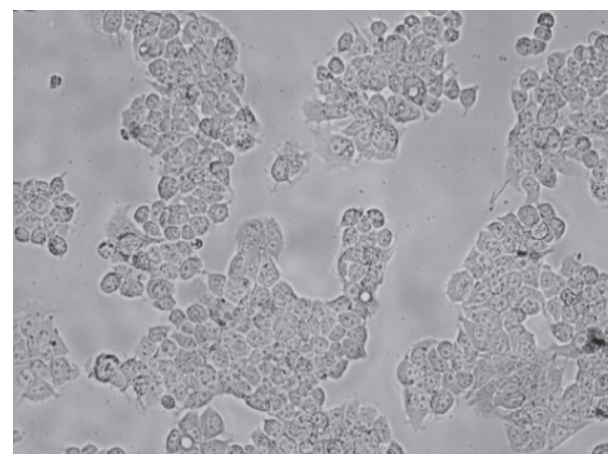

(a)

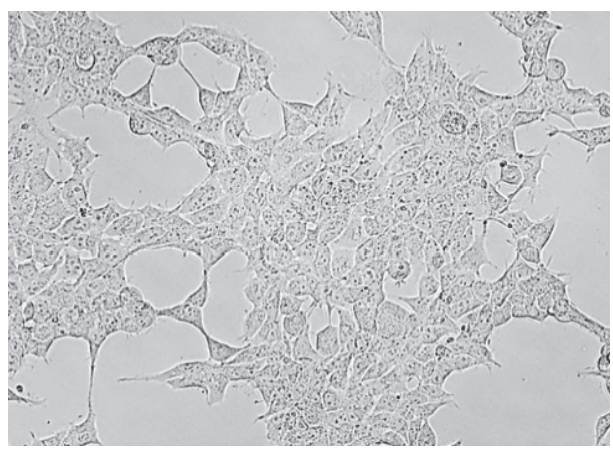

(c)

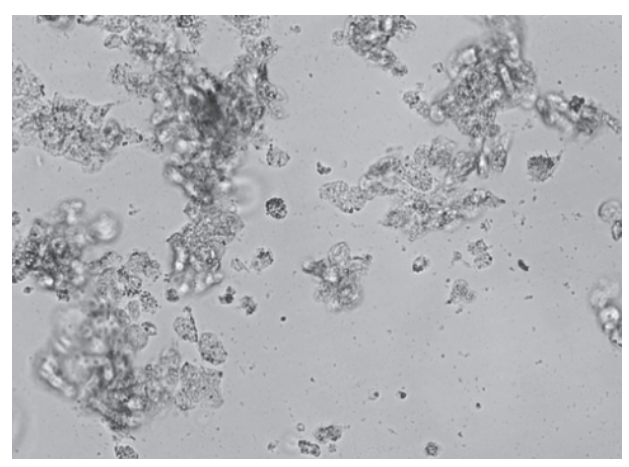

(b)

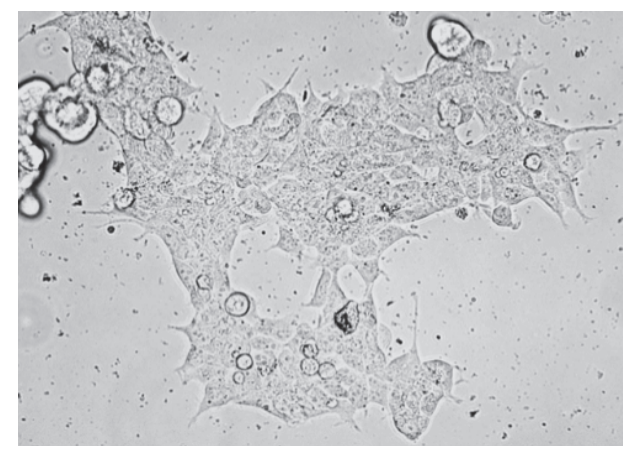

(d)

FIGURE 1: Effect of oregano EO on the cell morphology of hepatocarcinoma cell line (HepG2) and health renal cells (HEK293). The photographs were taken at a magnification $\times 40$. Images are representative of three independent experiments. (a) HepG2 (control); (b) HepG2 cells treated with oregano EO $(236 \mu \mathrm{g} / \mu \mathrm{L})$; (c) HEK293 (control); and (d) HEK293 cells treated with oregano EO $(236 \mu \mathrm{g} / \mu \mathrm{L})$.

savastanoi Janse, and P. syringae pv. phaseolicola Van Hall) compared with the synthetic antibiotic tetracycline. They resulted in the fact that the above-mentioned EOs were able to significantly inhibit the growth of tested bacterial strains especially against $\mathrm{G}+$ ve bacteria.

El-Massrry et al. (2009) [71] studied the antibacterial activity of different crude extracts from fresh leaves of $S$. terebinthifolius cultivated in Egypt and reported that these extracts exhibited higher antibacterial activity against $S$. aureus, $P$. aeruginosa, and $E$. coli. In a recent study, the EOs extracted from $V$. officinalis L., Majorana hortensis L., and Salvia officinalis L. were able to inhibit the growth of some phytopathogenic bacteria in a dose dependent manner such as $B$. megaterium, $C$. michiganensis, and B. mojavensis in the case of $V$. officinalis [72], whereas the highest reduction of $C$. michiganensis, $X$. campestris, and P. savastanoi was observed in the case of $S$. officinalis and M. hortensis. The mode of action of different EOs towards the bacterial cells in vitro is explained by permeabilization of cell membranes, loss of ions, leakage of macromolecules, and lysis [72].

7.2. Antifungal. Numerous plant EOs and their single constituents have been reported to inhibit postharvest fungi in vitro and in vivo. Several researchers reported that some plant EOs can be potentially utilized in controlling some serious phytopathogenic fungi such as $B$. cinerea $[73,74]$, Aspergillus spp. [75], Fusarium spp. [76], Penicillium spp. [77], and C. gloeosporioides Penz. [78].

Elshafie et al. (2015) [2] investigated the fact that the EOs obtained from $T$. vulgaris and $V$. officinalis can be effectively utilized for controlling brown rot infection on peach fruit caused by Monilinia laxa, M. fructicola, and M. fructigena. Clove EO extracted from Syzygium aromaticum (L.) Merr. \& Perry has been reported as a bioactive substance especially its active component monoterpene eugenol against $B$. cinerea, M. fructigena, P. expansum Link, and Phlyctema vagabunda Desm. in apples [79]. Oregano EO and its main single constituent carvacrol were reported to inhibit effectively the mycelium growth of Neofabraea alba (E. J. Guthrie) Verkley in apples [80].

Other studies also concluded the presence of significant potential fungicidal effects of some plant EOs such as thyme and vervain higher than chemical preparations in postharvest treatments against $M$. laxa, M. fructigena, and $M$. fructicola on peach fruit $[1,2]$. In the same mode, EOs of fennel (Foeniculum sativum Mill.), marjoram, oregano, and sage exhibited a fungicidal effect against $B$. cinerea and $P$. expansum in apples [81].

Elshafie et al. (2015) [17] evaluated the antifungal effect of the single components of O. vulgare EO (carvacrol, thymol, linalool, and trans-caryophyllene) against the postharvest pathogens M. laxa, M. fructigena, and M. fructicola (Figure 2). The fungicidal activity assay of the above four single 


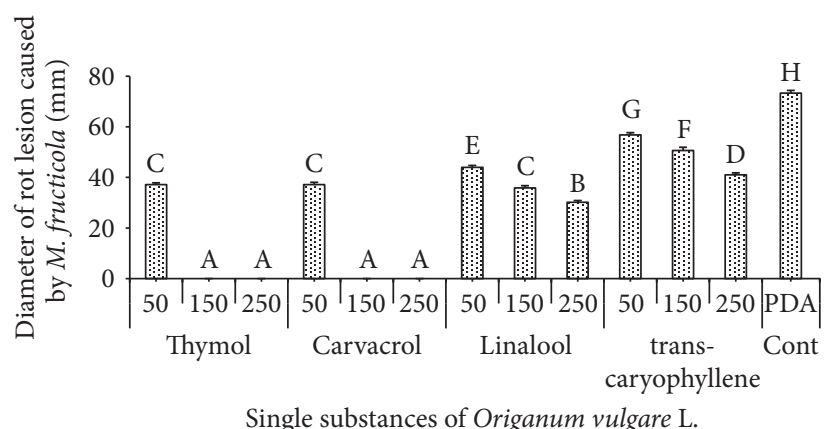

Single substances of Origanum vulgare L.

(a)

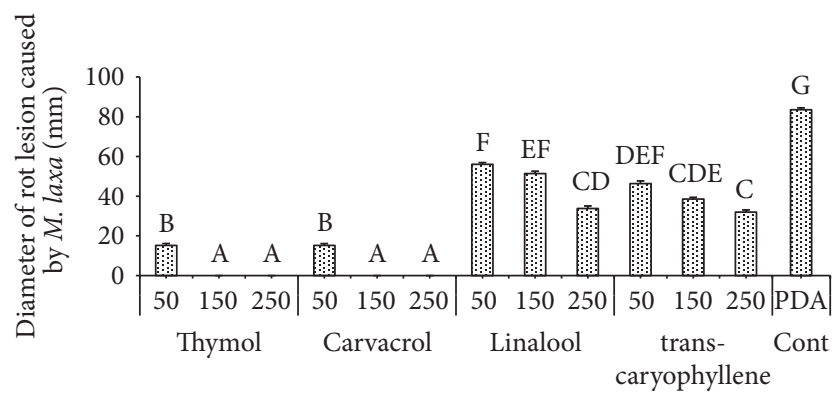

Single substances of Origanum vulgare L.

(b)

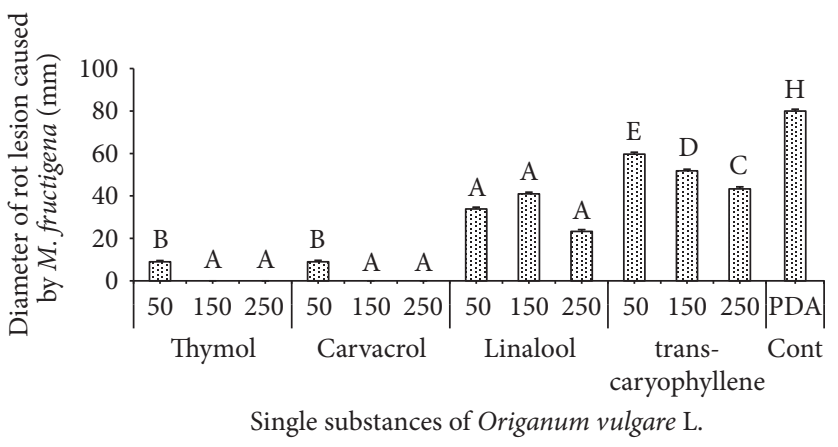

(c)

FIGURE 2: In vitro antifungal activity of the four single substances of $O$. vulgare EO against $M$. laxa, M. fructicola, and $M$. fructigena. Bars with different letters indicate mean values significantly different at $P<0.05$ according to Tukey test. Data are expressed as mean of three replicates \pm SE. 50, 150, and 250 are the concentrations of each single substance in ppm; PDA is potato dextrose agar.

components has been carried out in vitro according to the method of Soylu et al. (2010) [21] and the antifungal activity was expressed by measuring the diameter of mycelium growth [82]. They concluded that carvacrol and thymol have exhibited the highest activity in in vitro tests against all studied postharvest Monilinia pathogens. Linalool and transcaryophyllene showed low antifungal activity against all studied pathogens. However, thymol showed a fungitoxic effect while carvacrol and citral showed a fungistatic effect against the previous tested fungi.

In the same study, Elshafie et al. (2015) [17] reported that the bioactive treatments which exhibited the highest in vitro activity were selected for further in vivo experiments against the same postharvest pathogenic fungi and concluded that carvacrol and thymol showed a promising inhibition of the brown rot disease of peach fruit caused by $M$. laxa, $M$. fructicola, and M. fructigena. The antifungal effect is mainly attributed to the inhibition of both mycelium growth and spore germination. This hypothesis suggests that impeding the initial infection and the subsequent mycelial spread beyond the infection site will restrict the expression of disease.

\section{Conclusion}

A great many research articles investigating the biochemical properties of plant EOs have obtained interesting results in agricultural, clinical, and pharmaceutical fields. In conclusion, the use of EOs in pharmaceutical and agrochemical industries as natural alternatives for synthetic microbicide drugs is a field of growing interest. Plant EOs mentioned in the current review are considered promising natural alternatives to conventional pharmaceutical drugs. Moreover, there is still a need for more specific and rational research that deals with the method of application of those efficient EOs and their single constituents in agriculture and food industry for manufacturing new health-oriented products as well as novel natural pharmaceutical drugs.

\section{Conflicts of Interest}

The authors declare that they have no conflicts of interest.

\section{Authors' Contributions}

The authors contributed equally to manuscript.

\section{References}

[1] E. Mancini, I. Camele, H. S. Elshafie et al., "Chemical composition and biological activity of the essential oil of Origanum vulgare ssp. hirtum from different areas in the Southern Apennines (Italy)," Chemistry \& Biodiversity, vol. 11, no. 4, pp. 639-651, 2014. 
[2] H. S. Elshafie, E. Mancini, I. Camele, L. D. Martino, and V. De Feo, "In vivo antifungal activity of two essential oils from Mediterranean plants against postharvest brown rot disease of peach fruit," Industrial Crops and Products, vol. 66, pp. 11-15, 2015.

[3] B. Ali, N. A. Al-Wabel, S. Shams, A. Ahamad, S. A. Khan, and F. Anwar, "Essential oils used in aromatherapy: a systemic review," Asian Pacific Journal of Tropical Biomedicine, vol. 5, no. 8, pp. 601-611, 2015.

[4] M.-C. Ou, T.-F. Hsu, A. C. Lai, Y.-T. Lin, and C.-C. Lin, "Pain relief assessment by aromatic essential oil massage on outpatients with primary dysmenorrhea: a randomized, double-blind clinical trial," Journal of Obstetrics and Gynaecology Research, vol. 38, no. 5, pp. 817-822, 2012.

[5] P. Y. Kia, F. Safajou, M. Shahnazi, and H. Nazemiyeh, “The effect of lemon inhalation aromatherapy on nausea and vomiting of pregnancy: A double-blinded, randomized, controlled clinical trial," Iranian Red Crescent Medical Journal, vol. 16, no. 3, 2014.

[6] E. Watanabe, K. Kuchta, M. Kimura, H. W. I. Rauwald, T. Kamei, and J. Imanishi, "Effects of bergamot ( Citrus bergamia (Risso) Wright \& Arn.) essential oil aromatherapy on mood states, parasympathetic nervous system activity, and salivary cortisol levels in 41 healthy females," Forschende Komplementärmedizin, vol. 22, no. 1, pp. 43-49, 2015.

[7] K. H. C. Baser and G. Buchbauer, Handbook of Essential Oils: Science, Technology and Applications, CRC Press, Boca Raton, FL, USA, 2010.

[8] A. Pauli and H. Schilche, "In Vitro Antimicrobial activities of essential oils monographed in the European pharmacopoeia," in Handbook of essential oils; Science, Technology, and Applications, K. Hüsnü, C. Baser, and G. Buchbauer, Eds., Chapter 12, pp. 353-547, CRC Press, 2009.

[9] R. Tisserand, "Essential Oil Safety: A Guide for Health Care Professionals. Churchill Livingstone," Churchill Livingstone, 1995.

[10] C. M. O. Simoes and V. Spitzer, "Oleos volateis. In Farmacognosia: da planta ao medicamento," in Florianopolis: Editora da UFSC and Editora da Universidade/UFRGS, C. M. O. Simoes et al., Ed., Chapter 18, 1999.

[11] E. Guenther, "The Essential Oils/Gas chromatography mass spectrometry," in History-origin in plants production-Analysis, vol. 1, Krieger Publishing Company, Florida, FL, USa, 1st edition, 1972.

[12] H. Panda, Essential Oils Handbook, Chapter 110, National Institute of Industrial Research, New Delhi, India, 1st edition, 2003.

[13] C. F. Poole, The Essence of Chromatography, Elsevier, Amsterdam, Netherlands, 1st edition, 2003.

[14] M. B. Falkenberg, R. I. Santos, and C. M. O. Simoes, "Introducao a Analise Fitoquimica. In Farmacognosia: da planta ao medicamento," in Farmacognosia: da planta ao medicamento, C. M. O. Simoes et al., Ed., Chapter 10, Florianopolis: Editora da UFSC and Editora da Universidade/UFRGS, 1999.

[15] J. F. J. Todd, "Recommendations for nomenclature and symbolism for mass spectroscopy," International Journal of Mass Spectrometry, vol. 142, no. 3, pp. 209-240, 1995.

[16] O. D. Sparkman, Z. Penton, and F. G. Kitson, "Gas Chromatography and Mass Spectrometry: A Practical Guide," Academic Press, 2011.

[17] H. S. Elshafie, E. Mancini, S. Sakr et al., "Antifungal Activity of Some Constituents of Origanum vulgare L. Essential Oil
Against Postharvest Disease of Peach Fruit," Journal of Medicinal Food, vol. 18, no. 8, pp. 929-934, 2015.

[18] H. S. Elshafie, S. Sakr, S. M. Mang, S. Belviso, V. De Feo, and I. Camele, "Antimicrobial activity and chemical composition of three essential oils extracted from mediterranean aromatic plants," Journal of Medicinal Food, vol. 19, no. 11, pp. 1096-1103, 2016.

[19] H. S. Elshafie and I. Camele, "Investigating the effects of plant essential oils on post- harvest fruit decay," in Fungal pathogenicity, INTECH, Chapter 5, p. 16, Rijeka, Croatia, 2016.

[20] O. Adebayo, T. Dang, A. Bélanger, and S. Khanizadeh, "Antifungal Studies of Selected Essential Oils and a Commercial Formulation against Botrytis Cinerea," Journal of Food Research (JFR), vol. 2, no. 1, p. 217, 2012.

[21] E. M. Soylu, Ş. Kurt, and S. Soylu, "In vitro and in vivo antifungal activities of the essential oils of various plants against tomato grey mould disease agent Botrytis cinerea," International Journal of Food Microbiology, vol. 143, no. 3, pp. 183-189, 2010.

[22] M. Oussalah, S. Caillet, L. Saucier, and M. Lacroix, "Inhibitory effects of selected plant essential oils on the growth of four pathogenic bacteria: E. coli O157:H7, Salmonella Typhimurium, Staphylococcus aureus and Listeria monocytogenes," Food Control, vol. 18, no. 5, pp. 414-420, 2007.

[23] A. Pauli, "Antimicrobial properties of essential oil constituents," International Journal of Aromatherapy, vol. 11, no. 3, pp. 126-133, 2001.

[24] K. Fisher and C. A. Phillips, "The effect of lemon, orange and bergamot essential oils and their components on the survival of Campylobacter jejuni, Escherichia coli O157, Listeria monocytogenes, Bacillus cereus and Staphylococcus aureus in vitro and in food systems," Journal of Applied Microbiology, vol. 101, no. 6, pp. 1232-1240, 2006.

[25] S. G. Deans and G. Ritchie, "Antibacterial properties of plant essential oils," International Journal of Food Microbiology, vol. 5, no. 2, pp. 165-180, 1987.

[26] J. R. Möse and G. Lukas, "Zur Wirksamkeit einiger ätherischer Öle und deren Inhaltsstoffe auf Bakterien," ArzneimittelForschung/Drug Research, vol. 7, pp. 687-692, 1957.

[27] L. Panizzi, G. Flamini, P. L. Cioni, and I. Morelli, "Composition and antimicrobial properties of essential oils of four Mediterranean Lamiaceae," Journal of Ethnopharmacology, vol. 39, no. 3, pp. 167-170, 1993.

[28] J. Pellecuer, J. Allegrini, and M. Simeon De Buochberg, "Bactericidal and fungicidal essential oils," Revue de l'Institut Pasteur de Lyon, vol. 9, no. 2, pp. 135-159, 1976.

[29] R. S. Farag, Z. Y. Daw, F. M. Hewedi, and G. S. A. El-Baroty, "Antimicrobial activity of some Egyptian spice essential oils," Journal of Food Protection, vol. 52, no. 9, pp. 665-667, 1989.

[30] M. H. Lodhia, K. R. Bhatt, and V. S. Thaker, "Antibacterial activity of essential oils from palmarosa, evening primrose, lavender and tuberose," Indian Journal of Pharmaceutical Sciences, vol. 71, no. 2, pp. 134-136, 2009.

[31] K. Kathi and G. Aromatherapy, Aromatherapy, Alternate medicine, 1, p.59, Sri Satguru Publications, New Delhi, India, 1999.

[32] R. Tisser and T. Balacs, Essential oil safety: a guide for health professionals, Churchill Livingstone, Edinburgh, 1995.

[33] S. Kim, H.-J. Kim, J.-S. Yeo, S.-J. Hong, J.-M. Lee, and Y. Jeon, "The effect of lavender oil on stress, bispectral index values, and needle insertion pain in volunteers," The Journal of Alternative and Complementary Medicine, vol. 17, no. 9, pp. 823-826, 2011. 
[34] S. Price, "Aromatherapy Workbook: A Complete Guide to Understanding and Using Essential Oils," p. 320, Thorsons, London, UK, 1993.

[35] M. Russo, G. C. Galletti, P. Bocchini, and A. Carnacini, "Essential Oil Chemical Composition of Wild Populations of Italian Oregano Spice (Origanum vulgare ssp. hirtum (Link) Ietswaart): A Preliminary Evaluation of Their Use in Chemotaxonomy by Cluster Analysis. 1. Inflorescences," Journal of Agricultural and Food Chemistry, vol. 46, no. 9, pp. 3741-3746, 1998.

[36] L. De Martino, V. De Feo, C. Formisano, E. Mignola, and F. Senatore, "Chemical composition and antimicrobial activity of the essential oils from three chemotypes of origanum vulgare 1. ssp. hirtum (Link) ietswaart growing wild in campania (Southern Italy)," Molecules, vol. 14, no. 8, pp. 2735-2746, 2009.

[37] I. Camele, V. De Feo, L. Altieri, E. Mancini, L. De Martino, and G. Luigi Rana, "An attempt of postharvest orange fruit rot control using essential oils from Mediterranean plants," Journal of Medicinal Food, vol. 13, no. 6, pp. 1515-1523, 2010.

[38] J. Jalas, "Notes on Thymus L. (Labiatae) in Europe. I. Supraspecific classification and nomenclature," Botanical Journal of the Linnean Society, vol. 64, pp. 199-235, 1971.

[39] B. S. B. I. List, "Botanical Society of Britain and Ireland," Archived from the original xls, 2007.

[40] “Anise," in Encyclopeedia Britannica, T. S. Baynes, Ed., vol. 2, pp. 57-58, Charles Scribner's Sons, New York, NY, USA, 9th edition, 1878.

[41] H. Chisholm, "Anise , Encyclop $\mu$ dia Britannica , 2," in Encyclopeedia Britannica, vol. 2, p. 55, Cambridge University Press, 11th edition, 1911.

[42] V. M. Rodrigues, P. T. V. Rosa, M. O. M. Marques, A. J. Petenate, and M. A. A. Meireles, "Supercritical extraction of essential oil from aniseed (Pimpinella anisum L) using CO2: Solubility, kinetics, and composition data," Journal of Agricultural and Food Chemistry, vol. 51, no. 6, pp. 1518-1523, 2003.

[43] Caraway., "Word Crops Database," Retrieved, 2016.

[44] M. D. López, M. J. Jordán, and M. J. Pascual-Villalobos, “Toxic compounds in essential oils of coriander, caraway and basil active against stored rice pests," Journal of Stored Products Research, vol. 44, no. 3, pp. 273-278, 2008.

[45] R. Tisser and R. Young, Essential oil safety: a guide for health care professional, Churchill Livingstone, London, UK, 2nd edition, 2013.

[46] D. S. Vohra, Bach Flower Remedies: A Comprehensive Study, B. Jain Publishers, 2004.

[47] L. O. Orafidiya, E. O. Agbani, A. O. Oyedele, O. O. Babalola, and O. Onayemi, "Preliminary clinical tests on topical preparations of Ocimum gratissimum linn leaf essential oil for the treatment of Acne vulgaris," Clinical Drug Investigation, vol. 22, no. 5, pp. 313-319, 2002.

[48] A. Pauli and H. Schilcher, "Specific Selection of Essential Oil Compounds for Treatment of Children's Infection Diseases," Pharmaceuticals, vol. 1, no. 1, pp. 1-30, 2004.

[49] S. Stea, A. Beraudi, and D. De Pasquale, "Essential oils for complementary treatment of surgical patients: state of the art," Evidence-Based Complementary and Alternative Medicine, vol. 2014, Article ID 726341, 6 pages, 2014.

[50] L. Halcón and K. Milkus, "Staphylococcus aureus and wounds: a review of tea tree oil as a promising antimicrobial," American Journal of Infection Control, vol. 32, no. 7, pp. 402-408, 2004.
[51] A. Pauli, "Identification Strategy of Mechanism-Based Lipophilic Antimicrobials," in New Biocides Development, vol. 967 of ACS Symposium Series, pp. 213-268, American Chemical Society, Washington, DC, 2007.

[52] D. Rigano, C. Formisano, F. Senatore et al., "Intestinal antispasmodic effects of Helichrysum italicum (Roth) Don ssp. italicum and chemical identification of the active ingredients," Journal of Ethnopharmacology, vol. 150, no. 3, pp. 901-906, 2013.

[53] M. N. Boukhatem, A. Kameli, M. A. Ferhat, F. Saidi, and M. Mekarnia, "Rose geranium essential oil as a source of new and safe anti-inflammatory drugs," Libyan Journal of Medicine, vol. 8 , no. $1,2013$.

[54] A.-T. H. Mossa, A. A. Refaie, A. Ramadan, and J. Bouajila, "Antimutagenic effect of Origanum majorana L. essential oil against prallethrin-induced genotoxic damage in rat bone marrow cells," Journal of Medicinal Food, vol. 16, no. 12, pp. 11011107, 2013.

[55] A. C. Philip, "N-3 polyunsaturated fatty acids, inflammation and inflammatory diseases," The Journal Nutrition, vol. 83, pp. 1505-1519, 2006.

[56] A. E. Goulas and M. G. Kontominas, "Combined effect of light salting, modified atmosphere packaging and oregano essential oil on the shelf-life of sea bream (Sparus aurata): Biochemical and sensory attributes," Food Chemistry, vol. 100, no. 1, pp. 287296, 2007.

[57] R. Amorati, M. C. Foti, and L. Valgimigli, "Antioxidant activity of essential oils," Journal of Agricultural and Food Chemistry, vol. 61, no. 46, pp. 10835-10847, 2013.

[58] L. Valgimigli, "Essential oils: an overview on origins, chemistry, properties and uses," in Essential Oils as Natural Food Additives, L. Valgimigli, Ed., p. 24, Nova Science Publishers, New York, NY, USA, 2012.

[59] M. C. Foti, "Antioxidant properties of phenols," Journal of Pharmacy and Pharmacology, vol. 59, no. 12, pp. 1673-1685, 2007.

[60] A. Jemal, F. Bray, M. M. Center, J. Ferlay, E. Ward, and D. Forman, "Global cancer statistics," CA: A Cancer Journal for Clinicians, vol. 61, no. 2, pp. 69-90, 2011.

[61] N. Gautam, A. K. Mantha, and S. Mittal, "Essential oils and their constituents as anticancer agents: a mechanistic view," BioMed Research International, vol. 2014, Article ID 154106, 23 pages, 2014.

[62] J. D. Cha, Y. H. Kim, and J. Y. Kim, "Essential oil and 1,8-cineole from Artemisia lavandulaefolia induces apoptosis in KB Cells via mitochondrial stress and caspase activation," Food Science and Biotechnology, vol. 19, no. 1, pp. 185-191, 2010.

[63] G. K. Jayaprakasha, K. N. C. Murthy, R. M. Uckoo, and B. S. Patil, "Chemical composition of volatile oil from Citrus limettioides and their inhibition of colon cancer cell proliferation," Industrial Crops and Products, vol. 45, pp. 200-207, 2013.

[64] Y. Zu, H. Yu, L. Liang et al., "Activities of ten essential oils towards Propionibacterium acnes and PC-3, A-549 and MCF-7 cancer cells," Molecules, vol. 15, no. 5, pp. 3200-3210, 2010.

[65] S. Jayakumar, A. Madankumar, S. Asokkumar et al., "Potential preventive effect of carvacrol against diethylnitrosamineinduced hepatocellular carcinoma in rats," Molecular and Cellular Biochemistry, vol. 360, no. 1-2, pp. 51-60, 2012.

[66] D. D. Deb, G. Parimala, D. S. Saravana, and T. Chakraborty, "Effect of thymol on peripheral blood mononuclear cell PBMC and acute promyelotic cancer cell line HL-60," ChemicoBiological Interactions, vol. 193, no. 1, pp. 97-106, 2011. 
[67] W. Chaouki, D. Y. Leger, B. Liagre, J.-L. Beneytout, and M. Hmamouchi, "Citral inhibits cell proliferation and induces apoptosis and cell cycle arrest in MCF-7 cells," Fundamental \& Clinical Pharmacology, vol. 23, no. 5, pp. 549-556, 2009.

[68] H. Elshafie, M. Armentano, M. Carmosino, S. Bufo, V. De Feo, and I. Camele, "Cytotoxic Activity of Origanum Vulgare L. on Hepatocellular Carcinoma cell Line HepG2 and Evaluation of its Biological Activity," Molecules, vol. 22, no. 1435, pp. 1-16, 2017.

[69] C. O. da Fonseca, G. Schwartsmann, J. Fischer et al., "Preliminary results from a phase I/II study of perillyl alcohol intranasal administration in adults with recurrent malignant gliomas," World Neurosurgery, vol. 70, no. 3, pp. 259-266, 2008.

[70] H. S. Elshafie, N. Ghanney, S. M. Mang, A. Ferchichi, and I. Camele, "An in Vitro Attempt for Controlling Severe Phytopathogens and Human Pathogens Using Essential Oils from Mediterranean Plants of Genus Schinus," Journal of Medicinal Food, vol. 19, no. 3, pp. 266-273, 2016.

[71] K. F. El-Massrry, A. H. El-Ghorab, H. A. Shaaban, and T. Shibamoto, "Chemical compositions and antioxidant/antimicrobial activities of various samples prepared from Schinus terebinthifolius leaves cultivated in Egypt," Journal of Agricultural and Food Chemistry, vol. 57, no. 12, pp. 5265-5270, 2009.

[72] F. Bakkali, S. Averbeck, D. Averbeck, and M. Idaomar, "Biological effects of essential oils-a review," Food and Chemical Toxicology, vol. 46, no. 2, pp. 446-475, 2008.

[73] C. L. Wilson, J. M. Solar, A. El Ghaouth, and M. E. Wisniewski, "Rapid evaluation of plant extracts and essential oils for antifungal activity against Botrytis cinerea," Plant Disease, vol. 81, no. 2, pp. 204-210, 1997.

[74] C. Bouchra, M. Achouri, L. M. I. Hassani, and M. Hmamouchi, "Chemical composition and antifungal activity of essential oils of seven Moroccan Labiatae against Botrytis cinerea Pers: Fr," Journal of Ethnopharmacology, vol. 89, no. 1, pp. 165-169, 2003.

[75] M. U. Rahman and S. Gul, "Mycotoxic effects of Thymus serpyllum oil on the asexual reproduction of Aspergillus species," Journal of Essential Oil Research, vol. 15, no. 3, pp. 168-171, 2003.

[76] D. J. Daferera, B. N. Ziogas, and M. G. Polissiou, "The effectiveness of plant essential oils on the growth of Botrytis cinerea, Fusarium sp. and Clavibacter michiganensis subsp. Michiganensis," Crop Protection, vol. 22, no. 1, pp. 39-44, 2003.

[77] G. Arras, M. Aggabio, A. Piga, and G. DHallewin, "Fungicide effect of volatile compounds of Thymus capitatus," Acta Horticulturae, vol. 379, pp. 593-600, 1995.

[78] F. L. Palhano, T. T. B. Vilches, R. B. Santos, M. T. D. Orlando, J. A. Ventura, and P. M. B. Fernandes, "Inactivation of Colletotrichum gloeosporioides spores by high hydrostatic pressure combined with citral or lemongrass essential oil," International Journal of Food Microbiology, vol. 95, no. 1, pp. 6166, 2004.

[79] G. K. Kishore, S. Pande, and S. Harish, "Evaluation of essential oils and their components for broad-spectrum antifungal activity and control of late leaf spot and crown rot diseases in peanut," Plant Disease, vol. 91, no. 4, pp. 375-379, 2007.

[80] N. Tabanca, B. Demirci, S. L. Crockett, K. H. C. Başer, and D. E. Wedge, "Chemical composition and antifungal activity of Arnica longifolia, Aster hesperius, and Chrysothamnus nauseosus essential oils," Journal of Agricultural and Food Chemistry, vol. 55, no. 21, pp. 8430-8435, 2007.

[81] J. G. Lopez-Reyes, D. Spadaro, M. L. Gullinoa, and A. Garibaldia, "Efficacy of plant essential oils on postharvest control of rot caused by fungi on four cultivars of apples in vivo," Flavour and Fragrance Journal, vol. 25, no. 3, pp. 171-177, 2010.
[82] I. Camele, L. Altieri, L. de Martino, V. de Feo, E. Mancini, and G. L. Rana, "In vitro control of post-harvest fruit rot fungi by some plant essential oil components," International Journal of Molecular Sciences, vol. 13, no. 2, pp. 2290-2300, 2012. 

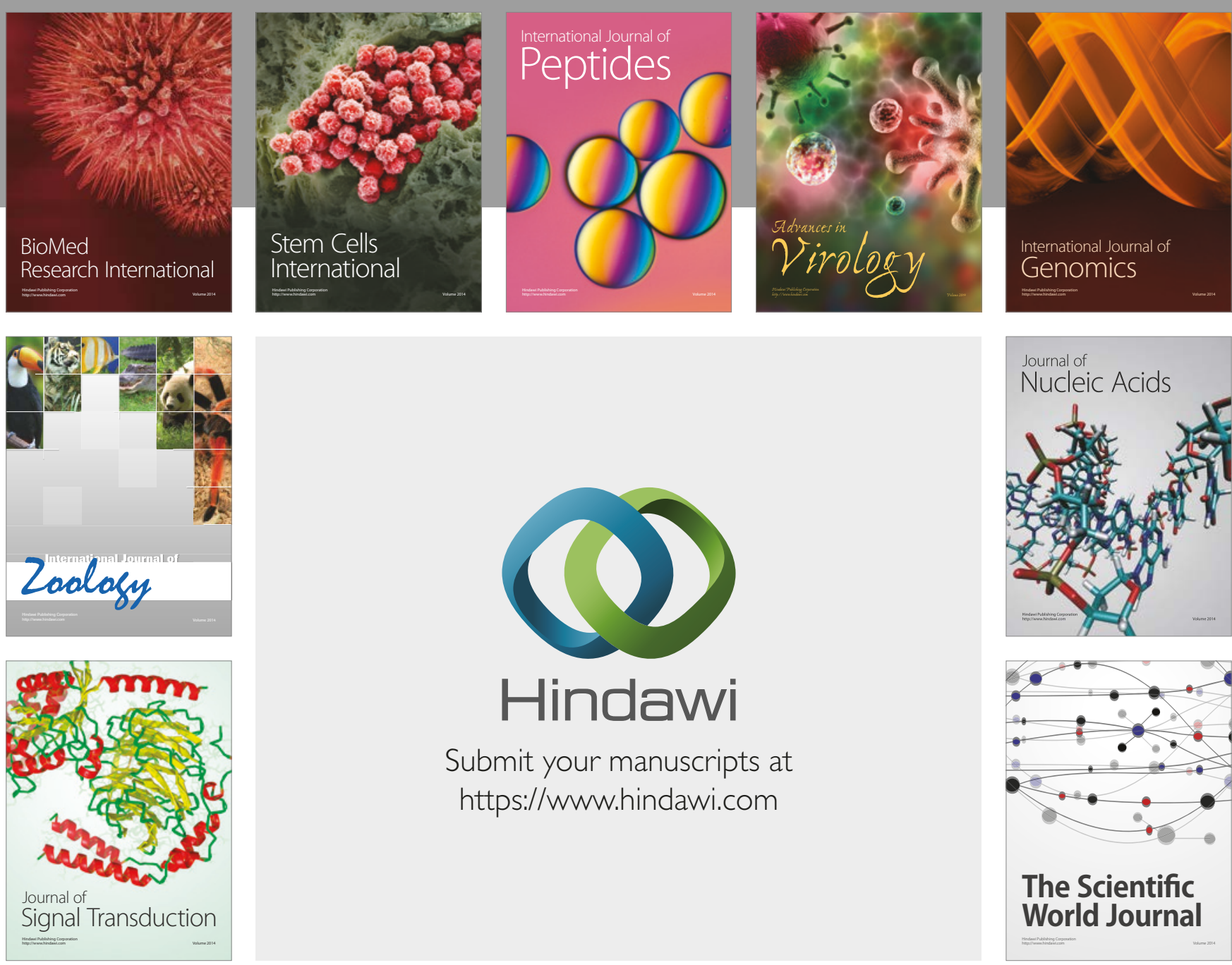

Submit your manuscripts at

https://www.hindawi.com
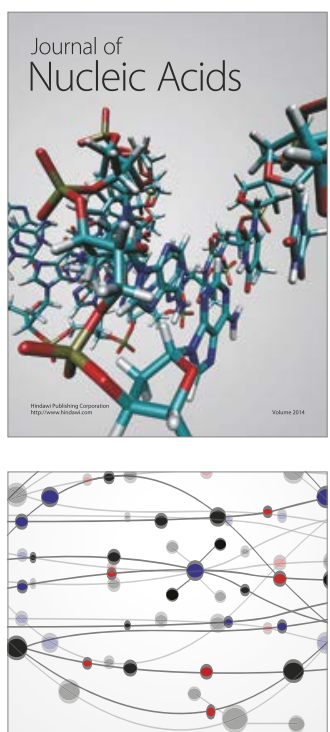

The Scientific World Journal

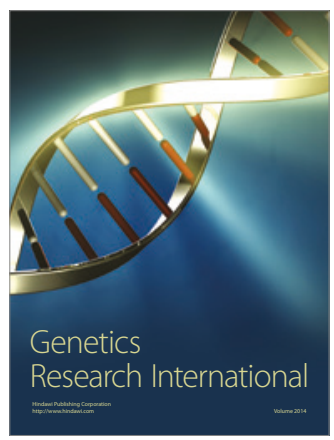

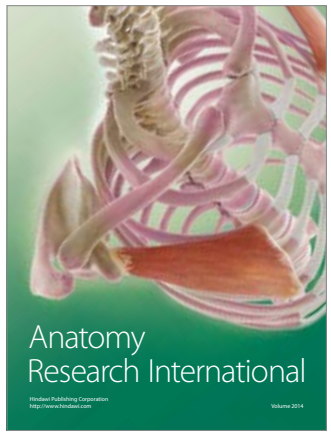

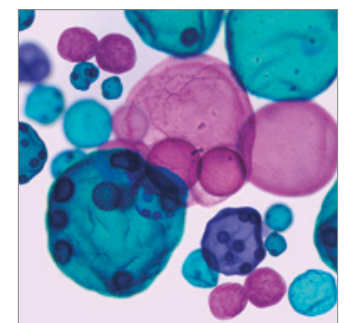

International Journal of Microbiology
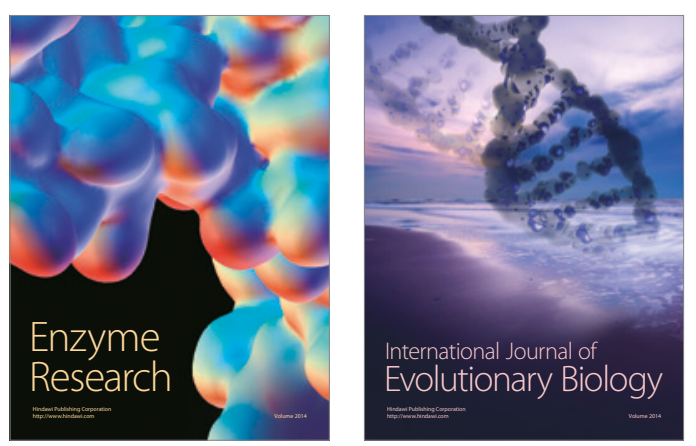
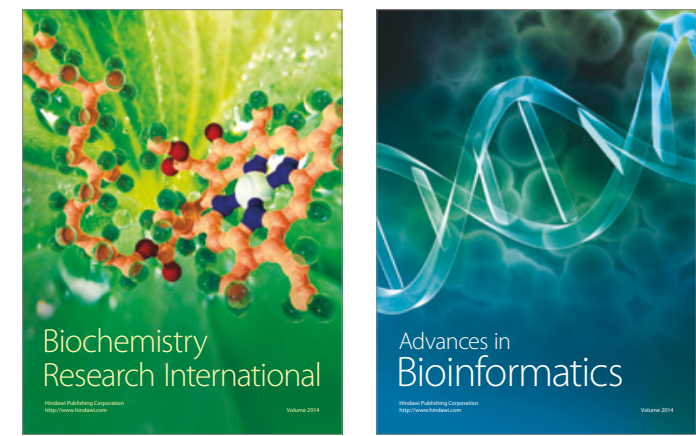

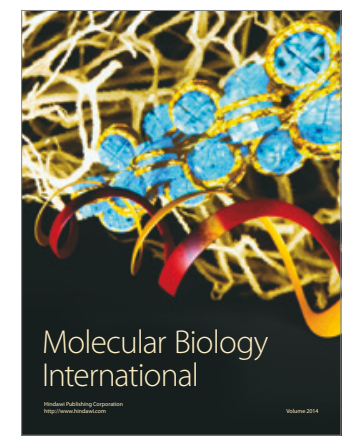

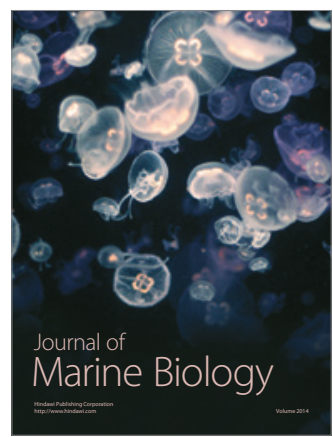

